\title{
Reliability of EMG activity in complete denture users during simulation of activities of daily living
}

\author{
Reprodutibilidade da atividade eletromiográfica em usuários de \\ próteses totais durante simulação de atividades de vida diária
}

\begin{abstract}
Purpose: To describe a kinesiologic EMG method and determine the reliability of EMG activity of representative muscles of mastication (temporal, masseter), posture of neck (sternocleidomastoid, trapezius) and trunk (rectus abdominis, paravertebral), and lower extremity strength (rectus femoris, medial gastrocnemius) during simulation of activities of daily living.

Methods: Ten edentulous healthy women (age: $58.2 \pm 5.6 \mathrm{yr}$ old) were tested with and without their dentures. EMG signals were recorded for each subject during three trials of each kinesiologic test: to stand up/sit down on a chair (TC), to rise/lie down in the bed (TB), and to lift/lower bags (TW). The same-day reprodutibility of the EMG values was estimated by test-retest reliability analyses. For each test (TC, TB, and TW) the intraclass correlation coefficient (ICC) and $95 \%$ confidence interval were estimated stratified by muscle, presence or not of complete dentures, and movement during the test (up and down) considering the three repetitions per subject to assess consistency.

Results: All muscles showed activation during the tests. The method yielded moderate to high ICCs; the highest test-retest reliability levels were estimated for the sternocleidomastoid (0.82-0.97) and paravertebral (0.86-0.99) muscles.

Conclusion: These findings suggest that the described kinesiologic EMG method showed satisfactory reliability in this sample.
\end{abstract}

Key words: Electromyography; complete dentures; activities of daily living

\section{Resumo}

Objetivo: Descrever uma metodologia de EMG cinesiológica e determinar a reprodutibilidade da atividade eletromiográfica dos músculos mastigatórios (m. temporal e m. masseter), posturais do pescoço ( $\mathrm{mm}$. esternocleidomastoideo e trapézio), posturais do tronco $(\mathrm{mm}$. reto abdominal e paravertebrais) e de força das extremidades inferiores ( $\mathrm{mm}$. reto femoral e gastrocnemius medial) durante simulação de atividades de vida diária (AVDs).

Metodologia: A amostra foi constituída por dez mulheres saudáveis, usuárias de prótese total bimaxilar, com idade média de 58,2 anos. Foram realizados três testes AVDs: levantar/ sentar da cadeira (TCAD), levantar/deitar na cama (TCAM) e pegar/largar sacolas (TSAC). A reprodutibilidade dos valores EMG foi analisada por teste-reteste. Para cada teste AVD foram estimados coeficiente de correlação intraclasse $(\mathrm{CClC})$ e intervalo de confiança de $95 \% \mathrm{com}$ estratificação por músculo, condição com e sem prótese (suporte oclusal) e movimento durante o teste, considerando três repetições por sujeito para avaliar consistência.

Resultados: Todos os grupos musculares apresentaram ativação durante os testes simulando AVDs. O método utilizado mostrou reprodutibilidade satisfatória com CCICs considerados moderados a altos. Os maiores valores de $\mathrm{CClC}$ foram estimados para os $\mathrm{m}$. esternocleidomastoideo $(0,82$ a 0,97$)$ e m. paravertebrais $(0,86$ a 0,99).

Conclusão: Os resultados sugerem que o método de EMG cinesiológico descrito apresentou reprodutibilidade satisfatória nesta amostra.

Palavras-chave: Eletromiografia; cinesiologia aplicada; prótese total; atividades coditianas

\author{
Simone Michielon Baldisserotto ${ }^{a}$ \\ Dúcia Caldas Cosme da Trindade ${ }^{b}$ \\ Jefferson Fagundes Loss' \\ Rosemary Sadami Arai Shinkaid
}

\begin{abstract}
- Private Practice, Caxias do Sul, RS, Brazil ${ }^{b}$ Department of Restorative Dentistry, Federal University of Paraíba (UFPB), João Pessoa, PB, Brazil

c Department of Physical Education, Federal University of Rio Grande do Sul (UFRGS), Porto Alegre, RS, Brazil

d Department of Prosthodontics, Pontifical Catholic University of Rio Grande do Sul (PUCRS), Porto Alegre, RS, Brazil
\end{abstract}




\section{Introduction}

Physiological and pathological alterations in different body parts may contribute to postural changes, decline of physical capacity, and functional limitations in elderly people causing difficulties to perform routine tasks such as activities of daily living (ADLs). The functional relationship between muscles of body posture and of the stomatognathic system has been investigated in relation to dental occlusion. For example, experimental changes of occlusal support have been associated with alterations of posture, balance, and mobility (1-3). Likewise, variation of gait and reaction time to initiate a physical activity were found in edentulous elderly subjects when their complete dentures (occlusal support) were removed from the mouth (4-6). Some epidemiologic studies also have shown that compromised oral health and reduced masticatory capacity are related to decreased physical performance in the elderly (7-9). Therefore, the loss or impairment of occlusal support seem to be related to modifications of body posture and physical performance, yet it is unknown the impact of the impairment of dental occlusion on ADLs.

One method to study function, control, and learning of muscle activity during movements is the kinesiologic electromyography (EMG) using surface electrodes (10). In Dentistry most studies using EMG have analyzed the activity of masticatory and head and neck postural muscles in static conditions, such as rest, maximum mouth opening, and dental clenching. Coordination of masticatory, head and trunk postural muscles, and muscles of lower extremities were reported during voluntary maximum clenching in dentate subjects (11-13). Asymmetric contractions of masticatory (14), neck (15), and leg (16) muscles were observed during dental clenching against an occlusal interference. However, up to date no other study has analyzed the impact of occlusal support on muscles of different body parts during dynamic routine tasks.

The specific aim of this study was to describe and evaluate the reprodutibility of a method to quantify the EMG amplitude of multiple muscles related to mastication (temporal, masseter), posture of head and neck (sternocleidomastoid, trapezius), posture of the trunk (rectus abdominis, paravertebral), and lower extremity strength (rectus femoris, gastrocnemius medialis) during performance of a specific functional task.

\section{Methodology}

The research protocol was approved by the University's Ethics Committee and the Brazilian Ministry of Health (SISNEP CAAE-0602.0.002.000-05) in compliance with the Helsinki Declaration, and all participants signed an informed consent form. A convenience sample was recruited from the patients who received treatment at the Complete Dentures Clinics of the University Dental School. Eligibility criteria comprised edentulous women wearing complete dentures in both maxilla and mandible, with age between 50 and $70 \mathrm{yr}$ old. Exclusion criteria were: history of maxillofacial surgery in the previous three months, presence of head or neck myofascial pain, diagnosis of dementia, gait impairment, history of fracture of leg bones or knee surgery in the previous five years, report of arthritis and/or pain in the lower limbs, history of heart attack in the previous year, body mass index above 31. Ten subjects with age between 50 and 68 yr old (mean: 58.2, SD: 5.6) and body mass index between 20 and 30 (mean: 24, SD: 3 ) were selected and examined in the following sequence: clinical exam, measurement of anthropometric variables, and acquisition of EMG data.

\section{EMG Instrumentation}

Surface EMG was used to record the muscle activity of eight muscles, on the right side: masticatory (temporal, masseter), head and neck (sternocleidomastoid, trapezius), trunk (rectus abdominis, paravertebral), and lower limb (rectus femoris, gastrocnemius medialis) muscles. Disposable, self-adhesive, silver-silver chloride electrodes (Noraxon Inc., Scottsdale, AZ, USA), with bipolar configuration, $10 \mathrm{~mm}$ diameter and $20 \mathrm{~mm}$ inter-electrode distance between centers, were placed over the selected muscles bellies parallel to muscular fibers, according to standard anatomical landmarks (Table 1). One reference ground silver-silver chloride electrode (MediTrace 200 adult, Grafic Controls, New York, NY, USA) was attached over the left tibia. Before electrode placement, the skin sites were prepared by cleansing the area with $70 \%$ alcohol.

Table 1. Positioning of the bipolar electrodes on the evaluated muscles.

\begin{tabular}{|c|c|}
\hline Muscle & Electrode position \\
\hline $\begin{array}{l}\text { Anterior te } \\
\text { muscle }\end{array}$ & $\begin{array}{l}\text { Two reference lines: 1) straight line midway } \\
\text { between the mandibular angle and condylar } \\
\text { head, rotated forward with an inclination of } \\
20^{\circ} \text {; 2) line tangent to the auricle ear and } \\
\text { passing through the cantus. Last electrode at } \\
\text { the intersection of these two lines (17). }\end{array}$ \\
\hline Masseter muscle & $\begin{array}{l}\text { Parallel to the muscular fibers with the upper } \\
\text { pole of the electrode at the intersection } \\
\text { between the tragus-labial commissura and } \\
\text { the exocanthion-gonion lines (15). }\end{array}$ \\
\hline $\begin{array}{l}\text { Sternocleidom } \\
\text { muscle }\end{array}$ & $\begin{array}{l}\text { Parallel to the muscular with the upper pole } \\
\text { of the electrode at the same vertical height of } \\
\text { the gonion (15). }\end{array}$ \\
\hline $\begin{array}{l}\text { Trapezius muscle } \\
\text { (upper part) }\end{array}$ & $\begin{array}{l}\text { With the shoulder positioned in } 90^{\circ} \text { of } \\
\text { abduction, two electrodes were placed } \\
\text { parallel to the muscle fibers. One electrode } \\
\text { was supero-medial and one infero-lateral to } \\
\text { a point } 2 \mathrm{~cm} \text { lateral to one-half the distance } \\
\text { between C7 spinous process and the lateral } \\
\text { tip of the acromion process (17). }\end{array}$ \\
\hline $\begin{array}{l}\text { Rectus abdominis } \\
\text { muscle }\end{array}$ & $\begin{array}{l}6 \mathrm{~cm} \text { above the navel and } 3 \mathrm{~cm} \text { to the right of } \\
\text { the midline (18). }\end{array}$ \\
\hline $\begin{array}{l}\text { Paravertebral } \\
\text { muscles }\end{array}$ & $\begin{array}{l}\text { Between L1 and L2, lateral and parallel to } \\
\text { the spine. }\end{array}$ \\
\hline $\begin{array}{l}\text { Rectus femoris } \\
\text { muscle }\end{array}$ & $\begin{array}{l}10 \text { to } 15 \mathrm{~cm} \text { above the superior border of the } \\
\text { patella over the largest part of the muscle } \\
\text { belly parallel to the orientation of the muscle } \\
\text { fibers (19). }\end{array}$ \\
\hline $\begin{array}{l}\text { Gastrocnemius } \\
\text { medialis muscle }\end{array}$ & $\begin{array}{l}50.3 \pm 5.7 \% \text { distance from the medial side of } \\
\text { the popliteus cavity to the medial side of the } \\
\text { Achilles tendon insertion, starting from the } \\
\text { Achilles tendon (20). }\end{array}$ \\
\hline
\end{tabular}


Electromyographic activity was recorded using an eightchannel computerized instrument (Bortec Electronics Inc., Calgary, Canada) comprised of pre-amplifiers (fixed gain of 500) which were located approximately $10 \mathrm{~cm}$ away from the electrodes. The instrument was interfaced with a computer which presented the raw EMG data graphically and recorded them for later quantitative and qualitative analyses. The sampling frequency was set at $2,000 \mathrm{~Hz}$ for each channel.

\section{EMG Measurement Protocol}

Firstly, EMG signals were recorded during maximum voluntary isometric contraction (MVIC) of the tested muscles (Table 2). After a training period, the subject was asked to perform the MVIC test for each muscle for 3 to $5 \mathrm{~s}$, while being encouraged by one member of the research team to exert maximum force against a localized resistance. All MVIC data were collected in duplicate with a 1 min-interval for rest with the subject wearing dentures.

EMG signals were recorded during three tests simulating ADLs: to stand up/sit on a chair (TC), to rise/lie down in the bed (TB), and to lift/lower bags (TW). The subjects performed the trials with and without their dentures, i.e., occlusal support, and the order of the trials was randomly chosen to prevent bias from motor learning. Before the recording of the actual trials in triplicate for each occlusal support condition, the individuals practiced the movements. During the tests, one research member gave verbal instruction to the subject to standardize the timing of the movements. Description of the kinesiologic tests is detailed as follows:

1. To stand up/sit on a chair (TC). Initial position: subject sitting on a chair with $46 \mathrm{~cm}$ height, no arms or head support, trunk in a natural erect posture, head in alignment with the spine and facing forward, knees and hips in $90^{\circ}$ flexion, both feet completely flat on the floor. Movement: Predetermined timing to perform the movements and to rest $-5 \mathrm{~s}$ of rest/seated, $3 \mathrm{~s}$ to stand up, $5 \mathrm{~s}$ of rest/upright position, and $3 \mathrm{~s}$ to sit down.
2. To rise/lie down in the bed (TB). Initial position: subject lying on her left side on a bed with $80 \mathrm{~cm}$ height, head support, neck along the spine axis, hips flexed, legs off the bed and perpendicular to the floor, no feet support. Movement: The subject performed a rising movement of head and trunk until seated, using hands support on the bed. After a 5 s-rest interval the subject was instructed to lie down and return to the initial position. The test was performed in triplicate with $30 \mathrm{~s}$ for rest in the initial position.

3. To lift/lower bags (TW). Initial position: subject standing in the upright position; two rigid plastic containers with single handles ("bags") weighing $4 \mathrm{kgf}$ each were positioned on the floor on the right and left sides in the arms direction. Movement: The task was to bend the knees, hold the bags on the floor and lift them with the arms extended along the trunk until the upright body position, hold the bags sustained, and lower the bags to the floor. The predetermined timing to perform the movements was: $3 \mathrm{~s}$ to lift the bags from the floor, $3 \mathrm{~s}$ to sustain the bags in the upright position, and $3 \mathrm{~s}$ to lower the bags to the floor and return to the original position. This test was performed in triplicate with $3 \mathrm{~s}$ of rest between repetitions.

The tests were filmed with a digital camera (Sony Digital Video Camera Recorder, DCR-TRV10, Sony Corporation, Japan) in real time. The beginning and the end of each test movement were marked by a customized synchronizer device, which input an electric signal to the EMG recordings and emitted a light signal filmed simultaneously with the subject performing the task. The image films were analyzed in static windows (1/30 s each window), and any discrepancies among body movement, light signal, and electric signal were manually checked and corrected.

\section{Analysis of EMG signals}

EMG signals were recorded for each subject during eight tasks: two repetitions of MVIC and three trials of each kinesiologic test when the individual was wearing and not wearing complete dentures.

Table 2. Procedures to obtain the maximum voluntary isometric contraction (MVIC) of the evaluated muscles.

\begin{tabular}{|c|c|c|}
\hline Muscle & Initial position & Mvic test \\
\hline Temporal and masseter muscles & $\begin{array}{l}\text { Sitting in an erect posture with no } \\
\text { head support }\end{array}$ & $\begin{array}{l}\text { Maximal voluntary dental clenching at the } \\
\text { intercuspal position }\end{array}$ \\
\hline $\begin{array}{l}\text { Trapezius and paravertebral } \\
\text { muscles }\end{array}$ & Lumbar-extension dynamometer & $\begin{array}{l}\text { Maximal lumbar extension against } \\
\text { dynamometer (isometric lumbar-extension } \\
\text { strength test) }\end{array}$ \\
\hline Rectus femoris muscle & $\begin{array}{l}\text { Sitting on the bed; hips flexed to } \\
80^{\circ} \text { and knees flexed to } 90^{\circ}\end{array}$ & $\begin{array}{l}\text { Extension of the leg against resistance } \\
\text { (researcher's hands) }\end{array}$ \\
\hline Sternocleidomastoid muscle & Supine position with legs flexed & $\begin{array}{l}\text { Maximal effort during anterior rotation of the } \\
\text { neck and head against resistance (hand of the } \\
\text { researcher on the subject's front) }\end{array}$ \\
\hline Rectus abdominis muscle & Supine position with legs flexed & $\begin{array}{l}\text { Flexion of the trunk against resistance (hands of } \\
\text { the researcher on the subject's shoulders) }\end{array}$ \\
\hline Gastrocnemius muscle & Supine position & $\begin{array}{l}\text { Extension of the foot against resistance } \\
\text { (researcher's shoulder) }\end{array}$ \\
\hline
\end{tabular}


The analogical EMG signal was amplified, digitized and digitally filtered. To process and analyze the EMG signals a software (SAD 32, version 2.59b) developed by the Laboratory of Mechanical Measurements (LMM) of the Mechanical Engineering School, Federal University of Rio Grande do Sul (www.ufrgs.br/lmm) was used. Input signals were digitally filtered in the frequency domain with the Fast Fourier Transform (FFT) algorithm using a thirdorder Butterworth pass-band filter, with cut-off frequencies between 10 and $400 \mathrm{~Hz}$. The filtered signals were smoothened by computing the RMS value in 500 ms-moving windows and weighed by a Hamming function.

From the MVIC recordings two data were computed: the MVIC value to be used for signal normalization, and the value of EMG rest for each muscle to be used as a reference value. The assumed MVIC value was the maximum EMG value computed after the envelop procedure. The value of EMG rest was extracted from the region with the smallest muscle activation during $1 \mathrm{~s}$.

For the EMG recordings of the ADLs tests, within each subject, the signals were normalized by dividing the EMG signal of each muscle by the MVIC value, and multiplied by 100 (percent scale), it been expressed as a percentage of maximum EMG amplitude produced by the muscle and referred to as percent maximum voluntary isometric contraction (\% MVIC). After normalization, each signal was cut in the timespan corresponding to the subject movement, and the mean value was calculated. To obtain the final value of EMG amplitude for each muscle the rest EMG value was subtracted from the mean calculated value.

\section{Statistical analysis - Test-retest reliability}

The same-day reprodutibility of the EMG values for each muscle and of the duration of movement during the trial was estimated by test-retest reliability analyses using intraclass correlation coefficients (ICCs). For each test (TC, TB, and TW) the ICC score was estimated stratified by muscle, presence or not of complete dentures, and movement during the test (up and down) considering the three repetitions per subject to assess consistency. For all statistics, 95\% confidence intervals were estimated. The criteria proposed by Landis \& Kock (21) were used to interpret the agreement as: a) almost perfect: 0.80 to 1.00 ; b) substantial: 0.60 to 0.80 ; c) moderate: 0.40 to 0.60 ; d) regular: 0.20 to 0.40 ; e) discrete: 0 to 0.20 ; and f) poor: -1.00 to 0 .

\section{Results}

Table 3 shows the estimated values of intraclass correlation coefficients (ICCs) and the $95 \%$ confidence intervals for EMG values and duration of movement for the three tests per subject. Overall the ICCs can be considered moderate to high (ICC $=0.60$ to 0.99 ) for most items, but the $95 \%$ confidence intervals were wide for ICCs below 0.85 . The estimated reliability levels usually were larger and more homogeneous for the bag test (TW) than for the chair (TC) and bed (TB) tests. No consistent variation of stability was found for most muscles and for duration of movement when lifting or lowering bags, with or without dentures.

Table 3. Intraclass correlation coefficients and 95\% confidence intervals of the three repetitions of $\%$ MVIC and duration of movement ( $\mathrm{n}=30$ ).

\begin{tabular}{|c|c|c|c|c|c|c|}
\hline & \multicolumn{2}{|c|}{ Chair test } & \multicolumn{2}{|c|}{ Bed test } & \multicolumn{2}{|c|}{ Bags test } \\
\hline & $\begin{array}{c}\text { With } \\
\text { dentures }\end{array}$ & $\begin{array}{l}\text { Without } \\
\text { dentures }\end{array}$ & $\begin{array}{c}\text { With } \\
\text { dentures }\end{array}$ & $\begin{array}{l}\text { Without } \\
\text { dentures }\end{array}$ & $\begin{array}{c}\text { With } \\
\text { dentures }\end{array}$ & $\begin{array}{l}\text { Without } \\
\text { dentures }\end{array}$ \\
\hline $\begin{array}{l}\text { Temporal muscle } \\
\text { up } \\
\text { down }\end{array}$ & $\begin{array}{l}0.75[0.26-0.93] \\
0.52[-0.40-0.87]\end{array}$ & $\begin{array}{l}0.96[0.89-0.99] \\
0.97[0.92-0.99]\end{array}$ & $\begin{array}{l}0.30[-1.04-0.81] \\
0.70[0.13-0.92]\end{array}$ & $\begin{array}{l}0.98[0.93-0.99] \\
0.98[0.95-0.99]\end{array}$ & $\begin{array}{l}0.87[0.61-0.96] \\
0.93[0.78-0.98]\end{array}$ & $\begin{array}{l}0.99[0.96-0.99 \\
0.97[0.92-0.99\end{array}$ \\
\hline $\begin{array}{l}\text { Masseter muscle } \\
\text { up } \\
\text { down }\end{array}$ & $\begin{array}{l}0.66[0.01-0.91] \\
0.82[0.48-0.95]\end{array}$ & $\begin{array}{l}0.17[-1.42-0.78] \\
0.82[0.49-0.95]\end{array}$ & $\begin{array}{l}0.94[0.81-0.98] \\
0.78[0.36-0.94]\end{array}$ & $\begin{array}{l}0.97[0.91-0.99] \\
0.90[0.72-0.97]\end{array}$ & $\begin{array}{l}0.82[0.47-0.95] \\
0.79[0.38-0.94]\end{array}$ & $\begin{array}{l}0.90[0.71-0.97] \\
0.94[0.81-0.98]\end{array}$ \\
\hline $\begin{array}{l}\text { Sternocleidomastoid m. } \\
\text { up } \\
\text { down }\end{array}$ & $\begin{array}{l}0.93[0.79-0.98] \\
0.97[0.91-0.99]\end{array}$ & $\begin{array}{l}0.91[0.73-0.97] \\
0.87[0.62-0.97]\end{array}$ & $\begin{array}{l}0.92[0.76-0.98] \\
0.82[0.49-0.95]\end{array}$ & $\begin{array}{l}0.93[0.79-0.98] \\
0.85[0.57-0.96]\end{array}$ & $\begin{array}{l}0.87[0.61-0.96] \\
0.93[0.80-0.98]\end{array}$ & $\begin{array}{l}0.92[0.77-0.98] \\
0.89[0.68-0.97]\end{array}$ \\
\hline $\begin{array}{l}\text { Trapezius muscle } \\
\text { up } \\
\text { down }\end{array}$ & $\begin{array}{l}0.94[0.82-0.98] \\
0.96[0.90-0.99]\end{array}$ & $\begin{array}{l}0.62[0.12-0.90] \\
0.91[0.74-0.98]\end{array}$ & $\begin{array}{l}0.79[0.38-0.94] \\
0.97[0.90-0.99]\end{array}$ & $\begin{array}{l}0.80[0.41-0.95] \\
0.95[0.84-0.98]\end{array}$ & $\begin{array}{l}0.95[0.86-0.99] \\
0.98[0.95-0.99]\end{array}$ & $\begin{array}{l}0.96[0.88-0.99 \\
0.95[0.87-0.99\end{array}$ \\
\hline $\begin{array}{l}\text { Rectus abdominis muscle } \\
\text { up } \\
\text { down }\end{array}$ & $\begin{array}{l}0.93[0.81-0.98] \\
0.82[0.46-0.95]\end{array}$ & $\begin{array}{l}0.74[0.23-0.93] \\
0.91[0.74-0.98]\end{array}$ & $\begin{array}{l}0.95[0.85-0.99] \\
0.95[0.86-0.99]\end{array}$ & $\begin{array}{l}0.83[0.50-0.95] \\
0.96[0.88-0.99]\end{array}$ & $\begin{array}{l}0.98[0.93-0.99] \\
0.97[0.90-0.99]\end{array}$ & $\begin{array}{l}0.78[0.36-0.94 \\
0.94[0.84-0.98\end{array}$ \\
\hline $\begin{array}{l}\text { Paravertebral muscles } \\
\text { up } \\
\text { down }\end{array}$ & $\begin{array}{l}0.86[0.59-0.96] \\
0.96[0.89-0.99]\end{array}$ & $\begin{array}{l}0.86[0.58-0.96] \\
0.88[0.64-0.97]\end{array}$ & $\begin{array}{l}0.93[0.79-0.98] \\
0.94[0.82-0.98]\end{array}$ & $\begin{array}{l}0.95[0.84-0.98] \\
0.98[0.93-0.99]\end{array}$ & $\begin{array}{l}0.99[0.97-0.99] \\
0.93[0.80-0.98]\end{array}$ & $\begin{array}{l}0.97[0.92-0.99 \\
0.98[0.94-0.99\end{array}$ \\
\hline $\begin{array}{l}\text { Rectus femoris muscle } \\
\text { up } \\
\text { down }\end{array}$ & $\begin{array}{l}0.89[0.69-0.97] \\
0.56[-0.28-0.88]\end{array}$ & $\begin{array}{l}0.92[0.78-0.98] \\
0.99[0.97-0.99]\end{array}$ & $\begin{array}{l}0.70[0.12-0.92] \\
0.94[0.83-0.98]\end{array}$ & $\begin{array}{l}0.94[0.82-0.98] \\
0.99[0.96-0.99]\end{array}$ & $\begin{array}{l}0.94[0.83-0.98] \\
0.93[0.79-0.98]\end{array}$ & $\begin{array}{l}0.93[0.81-0.98] \\
0.98[0.94-0.99]\end{array}$ \\
\hline $\begin{array}{l}\text { Gastrocnemius muscle } \\
\text { up } \\
\text { down }\end{array}$ & $\begin{array}{l}0.66[0.02-0.91] \\
0.95[0.85-0.99]\end{array}$ & $\begin{array}{l}0.82[0.47-0.95] \\
0.95[0.84-0.98]\end{array}$ & $\begin{array}{l}0.16[-1.46-0.77] \\
0.79[0.38-0.94]\end{array}$ & $\begin{array}{l}\text { (not computed) } \\
0.78[0.36-0.94]\end{array}$ & $\begin{array}{l}0.90[0.71-0.97] \\
0.55[-0.32-0.88]\end{array}$ & $\begin{array}{l}0.78[0.37-0.94 \\
0.96[0.87-0.99\end{array}$ \\
\hline $\begin{array}{l}\text { Duration of movement } \\
\text { up } \\
\text { down }\end{array}$ & $\begin{array}{l}0.67[0.04-0.91] \\
0.90[0.70-0.97]\end{array}$ & $\begin{array}{l}0.88[0.64-0.97] \\
0.81[0.45-0.95]\end{array}$ & $\begin{array}{l}0.95[0.87-0.99] \\
0.90[0.72-0.97]\end{array}$ & $\begin{array}{l}0.83[0.53-0.96] \\
0.90[0.71-0.97]\end{array}$ & $\begin{array}{l}0.86[0.60-0.96] \\
0.82[0.47-0.95]\end{array}$ & $\begin{array}{l}0.92[0.75-0.98 \\
0.95[0.85-0.99]\end{array}$ \\
\hline
\end{tabular}


In relation to the muscle groups, the highest ICCs were estimated for the sternocleidomastoid and paravertebral muscles. The lowest ICCs and wider amplitude of variation were determined for the temporal, masseter and gastrocnemius muscles. Overall, there was no pattern of larger reprodutibility as a function of presence of dentures or type of movement during the ADLs tests.

\section{Discussion}

This study showed that all evaluated muscles had activation during the simulation of ADLs. Previous studies have shown that occlusal support in edentulous individuals with complete dentures is important to stabilize the mandibular position and maintain the vertical dimension during physical exercises improving the static and dynamic balance in the elderly (4-6). Furthermore, epidemiological studies in elderly people suggested that the occlusal condition is associated with dynamic strength of the lower limbs, agility, and balance (8).

Previous kinesiologic EMG studies reported samples composed by six to thirteen subjects tested to reach objects, lift box, and flexion shoulder, obtaining good reprodutibility of results (22-25). This is the first study to use kinesiologic EMG to evaluate the effect of occlusal support on masticatory, head and neck, trunk, and lower limb muscles simultaneously during complex functional tasks. Previous studies in dentate subjects reported alteration of muscular contraction pattern when the occlusal support was modified by introducing an experimental interference $(1,11-16)$. However, these studies used static positions; only Sasaki et al. (12) evaluated isometric and isokinetic exercises of the lower limbs and did not find any association between dental clenching and isokinetic exercises.

The kinesiologic tests selected for this study sought to simulate some everyday life activities. However, these activities do not require great physical effort, and it is possible that the potential alterations of EMG amplitude were not detected. This may be due to the small amplitude of muscle activity during the tested movements plus the necessary filter processing of the raw EMG signals, which may have eliminated a small difference of muscle activity. In some occasions a negative \% MVIC value was computed, which may have occurred because the rest EMG signal still could reflect some muscle activity corresponding to postural tonus. Moreover, the values of maximum contraction were obtained in isometric contraction, while the EMG activity during the ADLs tests was recorded in dynamic contraction.

In general, the reprodutibility of the method was satisfactory with estimation of ICCs considered moderate to high for most items besides the large confidence intervals. The test to lift and lower bags with weights was more reprodutible than the Bed and Chair Tests probably because the movements during the Bags Test were more systematic. The presence of dentures and the type of movement (Up versus Down) did not affect the reprodutibility of most muscles and of the duration of movement. The sternocleidomastoid and paravertebral muscles were the most stable muscles during all movements, which may be explained by the fact that the postural muscles of neck and trunk were more uniformly activated during these tasks. Conversely, the masticatory muscles (temporal and masseter) and the gastrocnemius muscle showed the largest variation of activation, particularly during the rising movement from the chair or bed. During isokinetic contractions, a number of factors may result in low ICC, such as the relative displacement of the surface electrodes and the active muscle tissue, changes of muscle length, modifications of muscle fibers, differences of effort, and alteration of torque with variation of movement (25). Furthermore, the variability among muscle groups may occur due to differences of subcutaneous tissue amount, electrode displacement, proportion of active muscle fibers, and crosstalk (25).

In summary, the method proved to be satisfactory reprodutible and might be used to study other subject groups with different conditions of occlusion, age, and general health. Additionally, further analyses of other EMG variables may help to evaluate the connection of different motor systems during functional daily tasks.

\section{Acknowledgments}

This study was partially supported by the Brazilian Ministry of Education and Culture (CAPES graduate scholarship) and the National Council for Scientific and Technological Development (CNPq/ Ministry of Science and Technology - PQ-304394/2006-8). We would like to thank Fabricio Macagnan, Marcelo Rohde, Michele Fonseca and William Osterkamp, from the Physical Therapy School, Pontifical Catholic University of Rio Grande do Sul (PUCRS), Porto Alegre, RS, Brazil, for their technical assistance.

\section{References}

1. Kibana Y, Ishijima T, Hirai T. Occlusal support and head posture. J Oral Rehabil 2002;29:58-63.

2. Fink M, Wähling K, Stiesch-Scholz M, Tschernitschek H. The functional relationship between the craniomandibular system, cervical spine, and the sacroiliac joint: A preliminary investigation. Cranio 2003;21:202-8.
3. Yoshino G, Higashi K, Nakamura T. Changes in weight distribution at the feet due to occlusal supporting zone loss during clenching. Cranio 2003;21:271-8.

4. Ishijima T, Hirai T, Koshino H, Konishi $Y$, Yokoyama Y. The relationship between occlusal support and physical exercise ability. J Oral Rehabil 1998;25:468-71. 
5. Watanabe I. Influence of wearing complete dentures on body balance in edentulous elderly. Kokubyo Gakkai Zasshi 1999;66:8-14.

6. Morozumi K, Yamamoto I, Fujiwara T, Nishiya T, Takeuchi Y, Umeki $\mathrm{C}$ et al. Effect of dentures wearing on motor reaction time and balance function in elderly people. J Physiol Anthropol Appl Human Sci 2004;23:129-37.

7. Österberg T, Mellström D, Sundh V. Dental health and functional ageing. A study of 70-year-old people. Community Dent Oral Epidemiol 1990;18:313-8.

8. Yamaga T, Yoshihara A, Ando Y, Yoshitake Y, Kimura Y, Shimada M et al. Relationship between dental occlusion an physical fitness in an elderly population. J Gerontology 2002;57A:M616-20.

9. Takata Y, Ansai T, Awano S, Hamasaki T, Yoshitake Y, et al. Relationship of physical fitness to chewing in an 80-year-old population. Oral Diseases 2004;10:44-9.

10. Soderberg GL, Knutson LM. A guide for use and interpretation of kinesiologic eletromyographic data. Physical Therapy 2000;8:485-98.

11. Clark GT, Browne PA, Nakano M, Yang Q. Co-activation of sternocleidomastoid muscles during maximum clenching. J Dent Res 1993;72:1499-502.

12. Sasaki Y, Ueno T, Taniguchi H, OhyamaT. Effect of clenching on isometric and isokinetic strength of ankle plantar flexion. J Med Dent Sci 1998;45:29-37.

13. Ehrlich R, Garlick D, Ninio M. The effect of jaw clenching on the electromyographic activities of 2 neck and 2 trunk muscles. J Orofac Pain 1999;13:115-20.

14. Ferrario VF, Sforza C, Serrao G, Colombo A, Schimitz JH. The effects of a single intercuspal interference on electromyographic characteristics of human masticatory muscles during maximal voluntary teeth clenching. Cranio 1999;17:184-8.

15. Ferrario VF, Sforza C, Dellavia C, Tartaglia GM. Evidence of an influence of asymmetrical occlusal interferences on the activity of the sternocleidomastoid muscle. J Oral Rehabil 2003;30:34-40.
16. Valentino B, Melito F. Functional relationships between the muscles of mastication and muscles of the leg. Surgical Radiology Anatomy $1991 ; 13: 33-7$.

17. Ekstrom RA, Soderberg GL, Donatelli RA. Normalization procedures using maximum voluntary isometric contractions for the serratus anterior e trapezius muscles during surface EMG analysis. Electromyogr Kinesiol 2005;15:418-28.

18. Guimarães ACS, Vaz MA, Campos MIA, Morantes R. The contribution of the rectus abdominis and rectus femoris in twelve selected abdominal exercises. An electromyographic study. J Sports Med Phys Fitness 1991;31:222-30.

19. Mathur S, Eng JJ, Maclntyre DL. Reliability of surface EMG during sustained contractions of the quadriceps. J Electromyogr Kinesiol 2005; 15:102-10.

20. Rainoldi A, Melchiorri G, Caruso I. A method for positioning electrodes during surface EMG recordings in lower limb muscles. J Neurosci Methods 2004;134:37-43.

21. Landis JR, Koch GG. The measurement of observer agreement for categorical data. Biometrics 1977;33:159-74.

22. Bonato P, Boissy P, Della Croce U, Roy SH. Changes in the surface EMG signal and the biomechanics of motion during a repetitive lifting task. IEEE Trans Neural Syst Rehabil Eng 2002;10: 38-47.

23. Stapley PJ, Pozzo T, Cheron G, Grishin A. Does the coordination between posture and movement during human whole-body reaching ensure center of mass stabilization? Exp Brain Res 1999;129: 134-46.

24. Larsson B, Karlberg C, Elert J, Gerdle B. Reproducibility of surface EMG during dynamic shoulder forward flexions: a study of clinically healthy subjects. Clin Physiol 1999; 19:433-9.

25. Tyler AE, Karst GM. Timing of muscle activity during reaching while standing: systematic changes with target distance. Gait Posture 2004;20:126-33. 